\title{
HIV IN NSW — CHANGING PATTERNS IN MAJOR RISK FACTORS
}

trong concerns about confidentiality of clients having human immunodeficiency virus (HIV) tests have made accurate determination of the true number of HIV infected people difficult. Our best estimate for the number of NSW residents who have acquired HIV infection is 10,496 (Public Health Bulletin, February 1992). Mechanisms are now in place to record more accurately the number of new infections.

Data on exposure and sex have not been collected for a large proportion of cases, as shown in Table 7.

\begin{tabular}{|lcc|}
\hline TABLE 7 & & \\
\cline { 1 - 1 } $\begin{array}{l}\text { REPORTING OF SEX AND EXPOSURE } \\
\text { DATA }\end{array}$ & \\
\hline Year & Exposure & \\
\hline & $\begin{array}{c}\text { Reported } \\
\%\end{array}$ & $\begin{array}{c}\text { Sex } \\
\text { Reported } \\
\%\end{array}$ \\
\hline 1984 & 26 & 48 \\
1985 & 30 & 66 \\
1986 & 34 & 76 \\
1987 & 52 & 88 \\
1988 & 68 & 97 \\
1989 & 60 & 96 \\
1990 & 56 & 89 \\
\hline
\end{tabular}

As HIV is principally a bloodborne virus, intravenous drug users (IVDUs) and people practising unsafe sex, homosexual males particularly, are groups at high risk for acquiring HIV infection.

\section{Numbers of new cases}

From 1987 to 1991 the number of new infections in males fell from 1769 to 648 (Figure 5). Most of the decline is attributable to a decrease in homosexually acquired infections, which peaked in 1987. In 1984, 10 new infections were reported in women (Figure 5). This rose to 68 in 1985, and in 1990 and 1991, 56 and 44 new infections respectively were reported in women. The high proportion of males has always been a feature of the epidemic. In 1984, 96 per cent of cases where sex was recorded were male. In 1991, 94 per cent of cases were male.

\section{FIGURE 5}

HIV NOTIFICATIONS BY SEX, NSW,

1984-1991

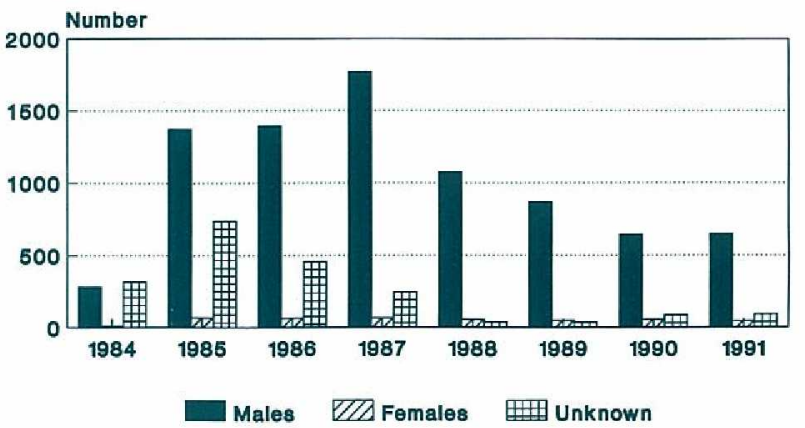

Male risk profile

The risk profile for HIV infections in males has altered significantly in the period 1984-1991 (Figure 6). Where exposure had been reported, 82 per cent of infections that occurred in 1991 were attributed to homosexual/bisexual exposure, compared to 100 per cent before 1985 . The number of males with homosexual/bisexually acquired HIV infection increased from 143 in 1984 to 885 in 1987, and then decreased to 326 in 1991 . The number of infections reported as attributable to intravenous drug usage (IVDU) rose to 34 in 1988 (Figure 7), and decreased to 17 in 1991. The number of combined exposure (IVDU and homo- or heterosexual) has displayed a similar trend, rising from 0 in 1984 to 25 in 1987, and falling to 12 in 1991.

\section{FIGURE 6}

MALE HIV NOTIFICATIONS BY RISK, NSW, 1984-1991

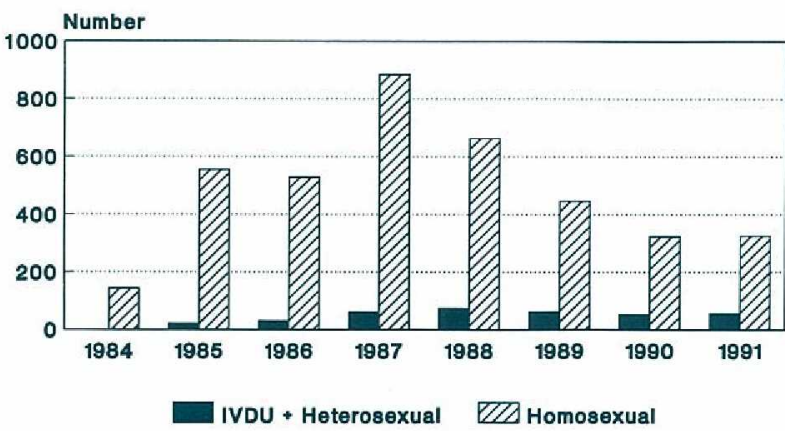

\section{FIGURE 7}

MALE HIV NOTIFICATIONS BY RISK, EXCLUDING HOMOSEXUALITY, NSW, 1984-1991

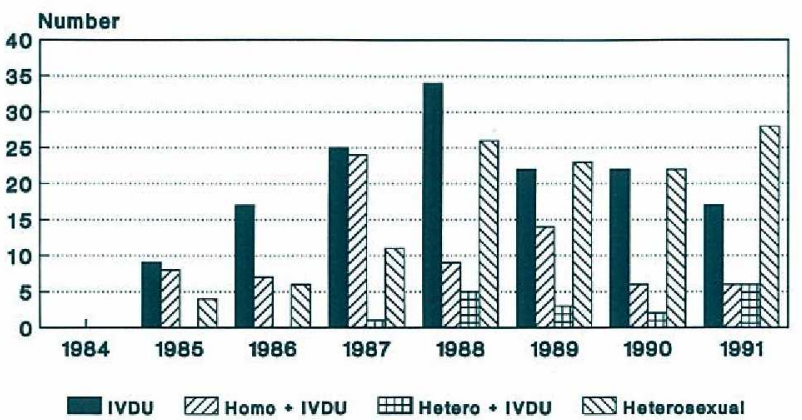

Male heterosexual exposure

The number of heterosexually acquired infections increased each year, from 0 in 1984 to 28 in 1991. In 1991 it accounted for 7.1 per cent of all reported infections with known 
exposure. This is in contrast to the general decline in numbers of new infections seen in other groups. The observed practice of young men in the 20-30 age group visiting Thailand, where HIV prevalence is high, with the thought they would engage in sexual activity while abroad, creates a potential for further increase in the size of this group. Such infections have been reported ${ }^{4}$.

\section{Female risk profile}

A total of 414 females infected with HIV have been reported from 1984 to 1991 . For only 44 per cent of the 414 cases was exposure recorded. A maximum number of 68 was recorded in 1985 (Figure 5). The annual number reported has remained fairly constant. If the heterosexuals and the IDVUs are considered together (Figure 8), it is possible to see a consistent increase from 1984 ( 0 cases) to 1989, when 29 infections occurred. After this the numbers declined again, with 19 and 12 cases occurring in 1990 and 1991 respectively.

\section{FIGURE 8}

FEMALE HIV NOTIFICATIONS BY RISK, NSW, 1984-1991

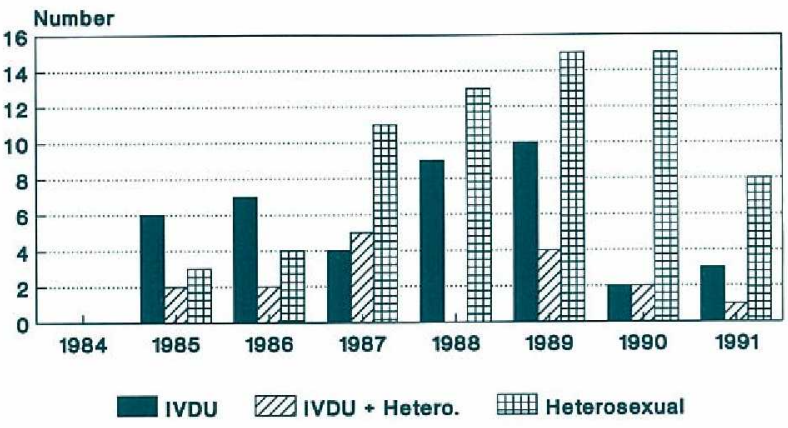

IVDUs

The number of cases of HIV infections in IVDUs not attributable to sexual contact declined from 48 in 1988 to 20 cases in 1991 . Where sexual contact was a cofactor a similar pattern was observed. In 1987, 31 cases occurred and in 1991, 14. Data from a number of studies have demonstrated low rates of HIV infection in the IVDU community ${ }^{2}$.

\section{Missing data}

The conclusions that have been made must be measured against the proportion of infections for which no exposure data are given. The Health Department is now making efforts to collect these data, for both new and historical data. Despite these limitations, trends, over years, show decreases in reported infections occurring in IVDUs and homosexual males. The reported increase in the number of heterosexually transmitted HIV infections in males indicates that signs of increased transmission to this group should be monitored closely.

\footnotetext{
1. Kaslow RA, Francis DP. The Epidemiology of AIDS. 1st Ed. Oxford 1. Kaslow RA, Francis

2. Kaldor J, Wodak A, Muir C et al. HIV Infection among IDUs in 2. Kaldor J, Wodak A, Muir C et al. HIV Infection an
Australia: A methodological review. In preparation.

3. Mulhall B, Lupton D, Thompson D et al. Planned sexual behaviour of Australian tourists travelling to Thailand. Abstract - Third Annual Conference on Medical and Scientific Aspects of HIV/AIDS. 1991. 4. Allworth A, Cunningham A, Donovan B et al. HIV infection in Australian men who have had heterosexual contact in South East Asia. Australian HIV Surveillance Report 1991 7: Supp 2.
}

\section{TABLE 9}

INFECTIOUS DISEASE NOTIFICATIONS, NSW FEBRUARY 1992

\begin{tabular}{|c|c|c|c|c|}
\hline \multirow[t]{3}{*}{ Condition } & \multicolumn{4}{|c|}{ Number of cases notified } \\
\hline & \multicolumn{2}{|c|}{ Period } & \multicolumn{2}{|c|}{ Cumulative } \\
\hline & $\begin{array}{c}\text { Feb } \\
1991 \\
\end{array}$ & $\begin{array}{c}\text { Feb } \\
1992\end{array}$ & $\begin{array}{l}\text { Feb } \\
1991\end{array}$ & $\begin{array}{c}\text { Feb } \\
1992\end{array}$ \\
\hline Adverse reaction & N/A & - & N/A & 3 \\
\hline AIDS & 34 & 4 & 56 & 11 \\
\hline Arboviral infection & 131 & 1 & 199 & 5 \\
\hline Brucellosis & - & - & - & - \\
\hline Cholera & - & - & - & - \\
\hline Diphtheria & - & - & - & - \\
\hline Foodborne illness (NOS) & 348 & 5 & 690 & 52 \\
\hline Gastroenteritis (instit.) & 6 & - & 8 & 3 \\
\hline Gonorrhoea & 21 & 1 & 83 & 23 \\
\hline $\mathrm{H}$ influenzae epiglottitis & 1 & - & - & 3 \\
\hline $\mathrm{H}$ influenzae $\mathrm{B}-$ meningitis & - & 4 & - & 10 \\
\hline $\mathrm{H}$ influenzae B - septicaemia & - & - & 1 & 1 \\
\hline $\mathrm{H}$ influenzae infection (NOS) & 5 & 1 & 9 & 5 \\
\hline Hepatitis A - acute viral & 30 & 6 & 38 & 104 \\
\hline Hepatitis B - acute viral & 1 & - & 4 & 11 \\
\hline Hepatitis B - chronic/carrier & - & 1 & - & 21 \\
\hline Hepatitis B - unspecified & 82 & 11 & 170 & 163 \\
\hline Hepatitis C - acute viral & 2 & 1 & 2 & 43 \\
\hline Hepatitis C - unspecified & 24 & 29 & 33 & 166 \\
\hline Hepatitis, acute viral (NOS) & 20 & - & 33 & 2 \\
\hline HIV infection & 83 & 39 & 155 & 92 \\
\hline Hydatid disease & 1 & - & 1 & 1 \\
\hline Legionnaires' disease & 1 & - & 7 & 2 \\
\hline Leprosy & - & - & - & 3 \\
\hline Leptospirosis & 7 & - & 13 & 1 \\
\hline Listeriosis & 1 & - & 3 & - \\
\hline Malaria & 4 & 1 & 9 & 5 \\
\hline Measles & 23 & 7 & 42 & 49 \\
\hline Meningococcal meningitis & 1 & - & 4 & - \\
\hline Meningococcal septicaemia & - & - & 3 & 2 \\
\hline Meningococcal infection (NOS) & 1 & 2 & 1 & \\
\hline Mumps & N/A & - & N/A & 3 \\
\hline Mycobacterial tuberculosis & 20 & 2 & 33 & 21 \\
\hline Mycobacterial - atypical & 6 & 3 & 7 & \\
\hline Mycobacterial infection (NOS) & 23 & - & 42 & 2 \\
\hline Pertussis & 8 & 1 & 22 & 6 \\
\hline Plague & - & - & - & - \\
\hline Poliomyelitis & - & - & - & - \\
\hline Q fever & 17 & - & 25 & \\
\hline Rubella & & 1 & 3 & \\
\hline Salmonella infection (NOS) & 142 & 7 & 316 & 102 \\
\hline Syphilis & 62 & 4 & 99 & 41 \\
\hline Tetanus & 1 & - & 1 & 1 \\
\hline Typhoid \& paratyphoid & 12 & - & 16 & 5 \\
\hline Typhus & - & - & & \\
\hline Viral haemorrhagic fevers & - & - & - & - \\
\hline Yellow fever & - & - & - & - \\
\hline
\end{tabular}

Please note that the data contained in this table are provisional and subject to change because of late reports or changes in case classification. Data are tabulated where possible by the disease onset date and not simply the date of notification or receipt of such notification. 
Important note: This double-sided insert replaces the article on pages 33-34.

\section{HIV IN NSW - CHANGING PATTERNS IN MAJOR RISK FACTORS}

Concerns about confidentiality of clients having human immunodeficiency virus (HIV) tests and a range of other factors have made accurate determination of the true number of HIV infected people difficult. Our best estimate for the number of NSW residents who have been diagnosed with HIV infection to the end of February is $10,496^{1}$. Mechanisms are now in place to record more accurately the number of new diagnoses.

It is important to note that the number of diagnoses made in a year does not mean that this number of people became infected with HIV in that year. For example, a person diagnosed in 1991 may have been infected many years earlier. The yearly notifications to the Health Department are only of new diagnoses, and therefore probably overestimate the number of new infections occurring in that year.

Data on exposure and sex have not been collected for a large proportion of diagnoses, as shown in Table 7.

As HIV is principally a bloodborne virus ${ }^{2}$, intravenous drug users who share injecting equipment (IVDUs) and people not practising safe sex ${ }^{\mathrm{a}}$ are groups at high risk for acquiring HIV infection.

\section{Numbers of new diagnoses}

From 1987 to 1991 the number of new diagnoses in males fell from 1769 to 648 (Figure 5). Most of the decline is attributable to a decrease in diagnoses of homosexually acquired infections which peaked in 1987. In 1984, 10 new diagnoses were reported in women (Figure 5). This rose to 68 in 1985, and in 1990 and 1991, 56 and 44 new diagnoses respectively, were reported in women. The high proportion of males has always been a feature of the epidemic. In 1984, 96 per cent of diagnoses where sex was recorded were male. In 1991, 94 per cent of diagnoses were male.

\section{Male risk profile}

The risk profile for HIV infection in males has altered significantly in the period 1984-1991 (Figure 6). Where exposure had been reported, 82 per cent of diagnoses that occurred in 1991 were attributed to homosexual/bisexual exposure, compared to 100 per cent before 1985 . The number of males diagnosed with homosexually/bisexually acquired HIV increased from 143 in 1984 to 885 in 1987, and then decreased to 326 in 1991 . The number diagnosed as attributable to intravenous drug usage (IVDU) rose to 34 in 1988 (Figure 7), and decreased to 17 in 1991. The number of diagnoses with combined exposures (IVDU and homo- or heterosexual) has displayed a similar trend, rising from 0 in 1984 to 25 in 1987, and falling to 12 in 1991.

\section{Male heterosexual exposure}

The number of males diagnosed with heterosexually acquired HIV increased from 0 in 1984 to 28 in 1991. In 1991 it accounted for 7.1 per cent of all reported diagnoses with known exposure. This is in contrast to the general decline in numbers of new diagnoses seen in other groups. The observed practice of young men in the 20-30 age group visiting Thailand, where HIV prevalence is high, with the thought they would engage in sexual activity while abroad ${ }^{3}$, creates a potential for further increase in the size of this group. Such infections have been reported ${ }^{4}$.

\section{Female risk profile}

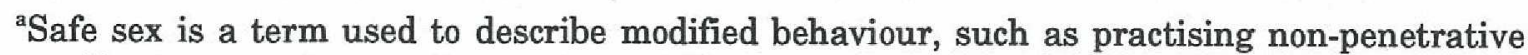
sex, and/or the use of protective equipment (for example condoms) designed to eliminate direct contact with seminal and vaginal fluids and blood. 
A total of 414 females diagnosed with HIV have been reported from 1984 to 1991 . Exposure was recorded for only 44 per cent of the 414 diagnoses. A maximum number of 68 diagnoses were recorded in 1985 (Figure 5). The annual number reported has remained fairly constant. If the heterosexuals and the IVDUs are considered together (Figure 8), it is possible to see a consistent increase from 1985 (11 diagnosed) to 1989, when 29 diagnoses were reported. After this the numbers declined again, with 19 and 12 diagnoses reported in 1990 and 1991 respectively.

\section{IVDUs}

The number of HIV diagnoses in IVDUs not attributable to sexual contact declined from 48 in 1988 to 20 in 1991 . Where sexual contact was a cofactor a similar pattern was observed. In 198731 diagnoses were reported and in 1991, 14. Published data on HIV in IVDUs other than men who also report homosexual contact indicate low rates of infection in the range 0.5 to 5 per cent $^{5}$.

\section{Missing data}

The conclusions that have been made must be measured against the proportion of diagnoses for which no exposure data are given. The NSW Health Department is now making efforts to collect these data, for both new and historical notifications. Despite these limitations trends show decreases in reported diagnoses in IVDUs and homosexual males.

The observed decrease in male homosexual diagnoses is supported by the findings of other studies that have shown a significant decrease in the rate of new infections ${ }^{6}$. The Sydney AIDS Prospective Study has shown no new infections over the last two years in a cohort of more than 1,000 homosexual men ${ }^{7}$. Another cohort of 535 homosexual men studied in 1986/87 found that the vast majority had adopted safe sex behaviour. A follow-up in late 1991 indicated an overall sustained level of safe behaviour, with a further increase in condom use and a decline in unprotected intercourse .

The reported increase in the number of diagnoses of heterosexually transmitted HIV infections in males indicates transmission to this group should be monitored closely.

Charles Blumer, Michael Levy

Epidemiology and Health Services Evaluation Branch

1. Anon. Public Health Bulletin. 1992 3:2.

2. Kaslow RA, Francis DP. The Epidemiology of AIDS. 1st Ed. Oxford University Press 1989.

3. Mulhall B, Lupton D, Thompson D et al. Planned sexual behaviour of Australian tourists travelling to Thailand. Abstract - Third Annual Conference on Medical and Scientific Aspects of HIV/AIDS. 1991.

4. Allworth A, Cunningham A, Donovan B et al. HIV infection in Australian men who have had heterosexual contact in South East Asia. Australian HFV Surveillance Report 1991;7:Supp 2.

5. Personal communication, Kaldor J. National Centre in HIV Epidemiology and Clinical Research. 30 March 1992.

6. Burcham J, Tindall B, Marmor $M$ et al. Incidence and risk factors for HIV seroconversion in a cohort of Sydney homosexual men. Med. J. Aust. 1989;150:634-639.

7. Personal communication, B. Tindall. National Centre in HIV Epidemiology and Clincal Research. 27 March 1992.

8. Connell RW, Crawford J, Kippax S et al, Facing the epidemic: changes in the sexual lives of gay and bisexual men in Australia and their implications for AIDS prevention strategies. Social Problems. 1989 36:4 pp 384-402.

9. Kippax S, Dowsett GW, Davis M et al. Social aspects of prevention of AIDS 1991 Sustaining safe sex survey. Technical report to Australian Federation of AIDS Organisations and the AIDS Council of New South Wales. Sydney. Macquarie University AIDS Research Unit. 